\title{
Evaluation of pain in children submitted to hematopoietic stem cell transplantation
}

\author{
Avaliação da dor em crianças submetidas ao transplante de células-tronco hematopoéticas
}

Adriana Corrêa Sampaio ${ }^{1}$, Nen Nalú Alves das Mercês ${ }^{1}$, Mauren Teresa Grubisich Mendes Tacla², Márcia Helena de Souza Freire ${ }^{1}$, Letícia Pontes ${ }^{1}$

Objective: to evaluate pain in children undergoing transplantation of hematopoietic stem cells. Methods: longitudinal and analytical research with children hospitalized for transplant of hematopoietic stem cells with Faces Pain Scale Revised, every four hours from hospital admission to hospital discharge analyzed with relative absolute frequency and chi-square test. Results: nine children aged four to nine years old were evaluated, totaling 1,095 ratings in $23.4 \%$ were reported with some pain score; of these, $38.9 \%$ were in hypo pharynx region; $78.8 \%$, moderate pain. The chi-square showed significance between pain scores weeks post-transplantation and pain existence among the analyzed children. Conclusion: although the pain has not affected large proportion of children, moderate and strong pain covered around $80.0 \%$ of complaints along the hematopoietic stem cell transplantation process. Thus, it is suggested that the evaluation of pain is one of the signs to be inserted in the protocols of nursing interventions in this context of caring.

Descriptor: Pediatric Nursing; Pain Measurement; Hematopoietic Stem Cell Transplantation.

Objetivo: avaliar a dor em crianças submetidas ao transplante de células-tronco hematopoéticas. Métodos: pesquisa longitudinal e analítica, com crianças internadas para transplante de células-tronco hematopoéticas, com escala Faces Pain Scale Revised, a cada quatro horas, do internamento à alta hospitalar, analisados com frequência absoluta, relativa e teste qui-quadrado. Resultados: nove crianças de quatro a nove anos de idade foram avaliadas, totalizando 1.095 avaliações, em 23,4\% foram relatados algum escore de dor; destas, 38,9\% foram em região hipofaríngea; 78,8\%, dor moderada. 0 qui-quadrado mostrou significância entre escores de dor e semanas pós-transplante e existência da dor entre as crianças analisadas. Conclusão: embora a dor não tenha acometido grande proporção de crianças, as dores moderada e forte abrangeram cerca de $80,0 \%$ das queixas, ao longo do processo de transplante de células-tronco hematopoéticas. Desta forma, sugere-se que a avaliação da dor seja um dos sinais a serem inseridos nos protocolos das intervenções de enfermagem nesse contexto de cuidar.

Descritores: Enfermagem Pediátrica; Medição da Dor; Transplante de Células-Tronco Hematopoiéticas.

\footnotetext{
${ }^{1}$ Universidade Federal do Paraná. Curitiba, PR, Brazil.

${ }^{2}$ Universidade Estadual de Londrina. Londrina, PR, Brazil. 


\section{Introduction}

Hematopoietic stem cell transplantation is a potentially curative therapy for malignant and non-malignant hematopoietic diseases in the recovery of hematopoietic cells ${ }^{(1)}$. When considering this therapeutic modality, the pain phenomenon is significantly present in children and other patients.

Pain is conceptualized by the International Association for the Study of Pain (IASP) as an emotional and sensory experience, caused by actual or potential injury to tissues, according to the person's previous experiences, and is always subjective ${ }^{(2)}$. The World Health Organization recommends that patients, who experience pain, including children, should be treated regardless of the cause ${ }^{(3)}$. Pain, considered as the fifth vital sign, should be evaluated along with the other signs in order to improve the quality of pain management in clinical settings ${ }^{(4)}$.

Suffering in the process of hematopoietic stem cell transplantation is multi casual and is present in the three phases. In the pre-transplant phase, pain occurs due to toxicity caused by the conditioning regimen $^{(5)}$, due to the use of high doses of chemotherapeutic drugs, associated or not with total body therapy, in order to induce immune suppression for remission of the disease of base. It is also due to the insertion of the Hickman®-type semi-implanted long-term central venous catheter ${ }^{(6)}$.

In transplantation, hematopoietic stem cell infusion can lead to mild to severe pain, cardiac, pulmonary and gastrointestinal changes ${ }^{(7)}$. Finally, in the post-transplant phase until grafting, pancytopenia, the pain episodes are of higher intensity ${ }^{(5)}$. Mucositis is one of the main causes of pain; it comes from the side effect of the regime of conditioning, administration of chemotherapy and/or radiotherapy. This consists of inflammation that affects the oral cavity, with possible extension to the entire gastrointestinal tract. In the initial phase, it presents edema and pain, and when advanced, ulcerations and bleeding. This process causes intense pain, with consequent need for continuous analgesic medication ${ }^{(5,8-9)}$.

From this perspective, there was investment in the construction of instruments for measuring pain, denominated one-dimensional and multidimensional. The one-dimensional ones evaluate the intensity, location and evolutionary pattern in the time of pain. These instruments can be of self-assessment, when the child himself reports through figures and colors the pattern of pain felt at the time, or by an evaluator who, by observing the child's behavior, determines the pain score. In addition to intensity and location, the multidimensional evaluates the quality of pain in the sensory, sensory, evaluative and temporal dimensions $^{(10)}$.

It is worth noting that, in order to assess the intensity of pain, adequate instruments are needed at the child's stage of cognitive development. It is gold standard, in the pre-verbal phase, in infants and newborns, facial expression and crying, and from the age of three, self-report, age at which the child reaches cognitive development to report pain stage. From the school stage, the child reaches the ability to understand order and numbering, and describes the degree of pain intensity, and for this age group, among the available one-dimensional instruments, the numerical scale is the most used, comprises a graduated line of zero to 10 , where zero means no pain and 10 , severe pain $^{(11)}$.

The Faces Pain Scale Revised (FPS-R), used by IASP, is translated into more than 60 languages and consists of a ruler with six-sided illustration, from left to right. In this scale, the child indicates which face resembles the pain at that moment, and the intensity of the pain is measured as the child's chosen score increases, each image characterizes the expression of pain and the respective score that varies from zero to $10^{(12)}$.

Therefore, pain assessment should be part of 
the nursing care interventions, to analyze the child's well-being, physical and psychological comfort ${ }^{(13)}$. In view of the complexity of the process of transplantation of hematopoietic stem cells, which has repercussions on experienced pain stages, it is important to systematically evaluate pain. This research aimed to evaluate pain in children submitted to transplantation of hematopoietic stem cells.

\section{Methods}

Longitudinal, analytical research performed in a bone marrow transplantation service of a public teaching hospital in the Southern region of Brazil. The inclusion criteria were: children hospitalized during the data collection period (from February to July 2015), for the hematopoietic stem cell transplantation process in the age group of four to 11 years, which is suggested for the understanding of FPS-R facial expressions $^{(14)}$. As exclusion criteria: children with visual deficit and/or incapacitated verbal communication, as in cases of intubations, deep and continuous sedation.

The children were recruited from the first day of hospitalization. For this reason, the parents were approached by the researcher, they received explanations about the objectives and method, and they proceeded to read the Informed Consent Term, to authorize the child's participation in the research, against the agreement, by means of the signature. The children were invited and received guidance for use of the FPS-R pain assessment scale. There was no refusal on the part of the parents, or of the children.

Then, for data collection, three instruments were used. The first, a questionnaire developed by the researchers, included the socio demographic and clinical profile of the participants. The second was the FPS-R scale, validated and adapted for use in Brazil ${ }^{(14)}$.

The third, a spreadsheet developed in Microsoft Windows Excel® 2010, for tabulation of the data collected, containing the variables: pain scores (absent, mild, moderate and strong); field to describe the location of pain (mouth, hypo pharyngeal region, abdomen, subclavian and others - relating to less frequent locations); and days related to blood, transplantation and post-transplantation. Pre-transplantation, referring to the five days prior to transplantation: day zero (day of transplantation) and post-transplantation (days following transplantation until the child's discharge), data recorded daily at the time of vital signs measurement. Exception made at collection times, in which the children were sleeping, refused or were absent from the service, for exams or radiotherapy.

The data were obtained during the period of hospitalization, starting five days before transplantation $(-5)$, considering the pre-stage, transplantation and post-transplantation of hematopoietic stem cells until hospital discharge.

The application of FPS-R occurred according to the guidelines of the study carried out with children under cancer treatment ${ }^{(14)}$. As for the guidelines offered for children, the first face, displays neutral expression, equals absence of pain, score zero; the second, with serious expression, is equivalent to mild pain, score two; the third, expression dejected, indicates moderate pain, score four; the fourth, sad expression, protruding forehead, is equivalent to moderate pain, score six; the fifth, eyes closed, forehead very protruding and low brows, equals strong pain, score eight; the sixth, expression of crying, mouth open, eyes closed and frowning is equivalent to severe pain, score $10^{(12)}$.

The collection was performed with daily evaluations, from the first day from the beginning of conditioning to hospital discharge, at 8:00am, 12:00am, $4: 00 \mathrm{pm}, 8: 00 \mathrm{pm}, 12: 00 \mathrm{pm}$ and 4:00am, coinciding with the closure of the water balance and verification of vital signs. It is reiterated that the periods of sleep of the child were respected, that is, the pain was not verified if he was sleeping. The evaluations occurred 
in the apartment where the child was located, in which the nursing professionals responsible for the care applied the scale. These were previously trained.

After the data were organized in the spreadsheet, the variables were synthesized, the absolute and percentage frequencies were analyzed, as well as the statistical analysis, using the chi-square test, agreeing with a significance level of $5 \%(\mathrm{p}<0.050)$. Objective of verifying the existence or not of evidence of correlation of variables tested: weeks of gauging and pain score.

Nine children, six aged four to six years old, participated in the study; five boys; seven were diagnosed with genetic diseases, including Fanconi's anemia; five were submitted to allogeneic hemopoietic stem cell transplantation. As for the origin, four were from the south of the country, being one a foreigner. Of the nine children, two underwent radiotherapy, associated with chemotherapy, as a conditioning protocol.

The research was approved by the Ethics and Research Committee of the institution, according to opinion no 784.683 and Certificate of Presentation for Ethical Appreciation no 34666314.0.0000.0096/2014; and respected national and international standards of research involving human beings.

\section{Results}

A total of 1,095 pain assessments were performed in the nine participating children, according to the previously defined schedules. Of this total, $850(77.6 \%)$ of the evaluations indicated no pain. Among the pain scores with 245 (22.4\%) of the evaluations; 147 (60.0\%) presented mild pain, 80 $(32.7 \%)$ moderate pain and $18(7.3 \%)$ severe pain, as shown in Table 1.

The chi-square test showed significance level $\mathrm{p}=0.001$, when comparing children and the existence of pain.
Table 1 - Self-reported pain intensity assessment according to the children

\begin{tabular}{|c|c|c|c|c|c|c|}
\hline \multirow{2}{*}{$\begin{array}{l}\text { Partici- } \\
\text { pants }\end{array}$} & \multirow{2}{*}{$\begin{array}{l}\text { № of } \\
\text { reviews }\end{array}$} & \multicolumn{4}{|c|}{$\begin{array}{c}\text { Pain assessment - Faces Pain Scale } \\
\text { Revised }\end{array}$} & \multirow[b]{2}{*}{$\mathbf{p}^{*}$} \\
\hline & & $\begin{array}{l}\text { Painless } \\
\text { n (\%) }\end{array}$ & $\begin{array}{l}\text { Light pain } \\
\text { n (\%) }\end{array}$ & $\begin{array}{c}\text { Moderate } \\
\text { pain } \\
\text { n }(\%)\end{array}$ & $\begin{array}{c}\text { Strong } \\
\text { pain } \\
\text { n }(\%)\end{array}$ & \\
\hline 1 & 123 & $71(57.7)$ & $34(27.6)$ & $16(13.0)$ & $2(1.6)$ & \\
\hline 2 & 128 & $95(74.2)$ & $26(20.3)$ & $4(3.1)$ & $3(2.3)$ & \\
\hline 3 & 191 & $154(80.6)$ & $14(7.3)$ & $22(11.5)$ & $1(0.5)$ & \\
\hline 4 & 102 & $100(98.0)$ & $1(1.0)$ & $1(1.0)$ & - & 0.001 \\
\hline 5 & 112 & $111(99.1)$ & - & $1(0.9)$ & - & \\
\hline 6 & 127 & $112(88.2)$ & $9(7.1)$ & $4(3.1)$ & $2(1.6)$ & \\
\hline 7 & 61 & $47(77.0)$ & $9(14.8)$ & $2(3.3)$ & $3(4.9)$ & \\
\hline 8 & 127 & $92(72.4)$ & $14(11.0)$ & $16(12.6)$ & $5(3.9)$ & \\
\hline 9 & 124 & $68(54.8)$ & $40(32.3)$ & $14(11.3)$ & $2(1.6)$ & \\
\hline Total & 1,095 & $850(77.6)$ & $147(13.4)$ & $80(7.3)$ & $18(1.6)$ & \\
\hline
\end{tabular}

There were 430 times of unfilled evaluations. Also, 157 unrealized evaluations were recorded, due to the fact that the child was sleeping, six evaluations refused and 13 absent evaluations, because the child was not in the sector at standard time.

Based on the analysis of the score and the location pointed out by the children, of the 245 evaluations, 16 (6.5\%) records did not happen associated with the location, therefore 229 notes were considered for this analysis. Prevalence of the hypo pharyngeal region was identified in 89 (38.9\%) evaluations, being 52 (37.4\%); 33 (43.4\%); and 4 (28.6\%), with mild, moderate and severe pain, respectively; followed by the mouth, 58 (25.3\%), with 43 (30.9\%) mild, 12 (15.8\%) moderate and 3 (21.4\%) strong; abdomen, 45 (19.7\%) in 27 (19.4\%) mild, 15 (19.7\%) moderate and $3(21.4 \%)$ strong; head 7 (3.0\%), 5 (3.6\%) mild and 2 (2.6\%) moderate; subclavian, 6 (2.6\%), with 3 
$(2.2 \%)$ mild, 2 moderate $(2.6 \%)$ and $1(7.1 \%)$ strong; and the group called 'others', which included several locations (forearm, arm, shoulder, ear, neck, leg, epigastric, perianal), representing 24 (10.5\%) evaluations in $9(6.5 \%)$ mild , $12(15.8 \%)$ moderate and 3 (21.4\%) strong.

In the analysis between the days of pain evaluation and the measured pain score, it was observed that in the week prior to transplantation, mild pain was verified in nine evaluations, representing $6.1 \%$, the moderate pain in three (3.8\%), and severe pain, two (11.1\%). On day zero, the day of transplantation, six $(2.6 \%)$ evaluations indicated a mild and moderate pain score, and the severe pain in one (5.6\%) evaluation. In the first and second post-transplant weeks (days +1 to +14 ), the pain scores were higher than the other weeks, of 147 pain reports, 109 (74.2\%) were mild pain, 80, 63 (78.8\%) of moderate pain; and 18, 14 (77.8\%), severe pain.

As a rule, the children were discharged from the hospital on the fourth and the beginning of the sixth week after transplantation. In this study, it was evidenced that pain is significantly reduced, both in frequency and intensity, from the third week after transplantation, according to Table 2.

Table 2 - Measurement of pain intensity from hospital admission to hospital discharge

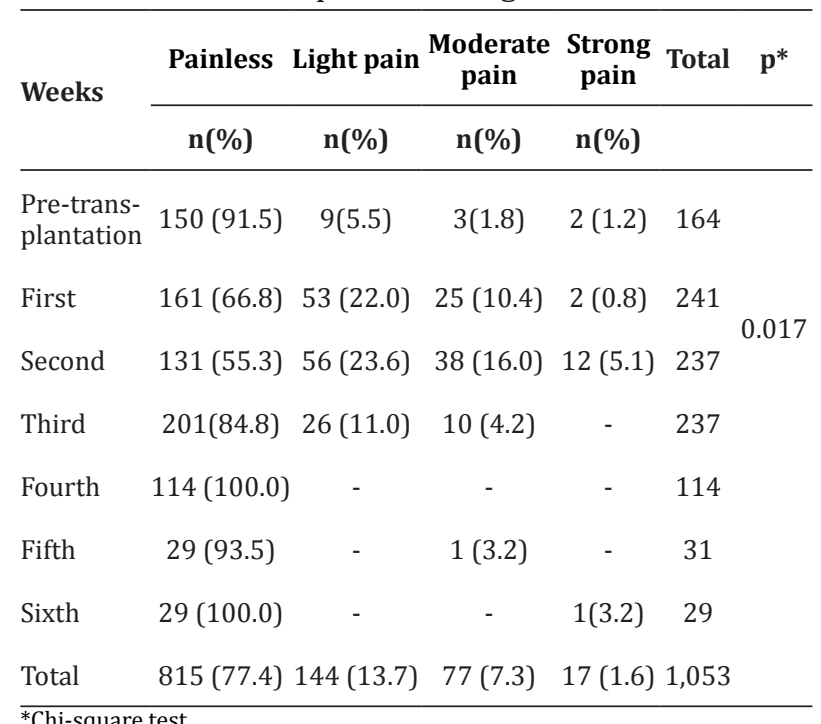

It is pointed out that the average stay of hospitalized children in the sector was 27.2 days. The chisquare test showed a significant difference $(p=0.017)$, showing statistical evidence of differences in the pain score with the hospitalization weeks, when compared to the first and second post-transplant weeks, showed an increase in pain scores and frequency compared to the other weeks.

\section{Discussion}

The limitations of this study are: the reduced number of participating children, which may be justified by the reduction of available beds due to the administrative issues of the Health Institution; the high proportion of information from unregistered variables; and, finally, the option of developing a hematopoietic stem cell transplantation in a hospital setting, justified by the adequacy of the research design to the practice scenario of one of the authors, a requirement of a professional master's program. These restrictions may limit the application of the study to the basis of discussion of other works, however, this study can be replicated in other similar scenarios or not.

The application of FPS-R, in general, was receptive to the evaluated children and allowed to analyze intensity or pain score, verify its prevalence; however, it was not the scope of this research to relate it to the monitoring of pharmacological treatment practices or not of pain, as found in a study in Portugal ${ }^{(10)}$.

This scale is considered to be reliable and has good psychometric properties, but in a study of 456 children in the pediatric emergency service in Cana$\mathrm{da}$, it diverged compared to the visual analogue scales and Color Analog Scale, both of which assessed pain intensity ${ }^{(15)}$.

The present study confirms that acute pain is present in children before and after transplantation of hematopoietic stem cells, with greater intensity and frequency in the first and second weeks after transplantation, however, it deserves attention in the weeks prior to transplantation. Days of adaptation of 
the child and family to the restrictive routines of the service, changes from the family environment to protective isolation, strict hygiene standards, changes in food; early onset of conditioning and side effects of chemotherapeutic and antiparasitic agents, including parental and child expectations, as to the risk of possible complications and death, generate feelings such as fear and anxiety in these situations ${ }^{(16)}$. In this hospitalization process, acute pain is present and frequent, caused by procedures such as venous, curative punctures or by the course of the disease itself ${ }^{(17)}$.

The previous result corroborates that observed in a prospective study, based on the Taxonomy of NANDA-International, Inc., with 738 medical records of children, from 28 days to 10 years, in which, among the seven major nursing diagnoses listed, acute pain was present in $7.1 \%^{(18)}$. It is clear from research that the diagnosis of acute pain is essential for the management of these patients undergoing transplantation of hematopoietic stem cells, so that nursing care guidance can be directed, with consequent qualification of the same and guarantee of patient safety.

Researches, conducted in the United States, have revealed incidences of mucositis above $90.0 \%$ in children submitted to hematopoietic stem cell transplantation ${ }^{(5,9)}$. According to the localizations of the pains of the children participating in the research presented here, with prevalence in the hypo pharyngeal region, mouth, including the abdomen and epigastric regions, in the category of 'others', it can be reiterated the problem of the mucositis in the transplant. In this discussion, it is emphasized the determination of this mucositis by the protocol of conditioning, with use of drugs predisposing to adverse effects of this modality. Likewise, it presents the problem in the post-transplant period.

It is understood that the protocols of conditioning are related to the incidence of mucositis, such as the use of Metrotexate and Fludarabine, which determine side effects, with frequent gastrointestinal toxicities, after use ${ }^{(5)}$.

Abdominal pain, because it is multi causal, may or may not be associated with low gastrointestinal mucositis, periods of prolonged fasting, irritation of the gastric mucosa due to the mechanism of enzymatic release of drugs mainly antibiotics, immunosuppressant drugs and chemotherapeutics used in cell transplantation hematopoietic stem cells. However, to better elucidate the cause of abdominal pain, invasive examinations (colonoscopy) would be necessary, an unfeasible procedure for patients with aplasia.

It is also reported that abdominal pain may be associated with diarrheal processes during the period of hospitalization for hematopoietic stem cell transplantation and is related to multiple factors: mucositis, graft-versus-host disease, gastrointestinal infections, veno-occlusive disease ${ }^{(5)}$.

The complaints of six among the nine children investigated were related to pain in the subclavian and cervical regions, certainly related to the postoperative period of the Hickman ${ }^{\circledR}$ catheter implant, including the catheter insertion and exit ostia. It is also added to this situation of postoperative pain the region of skin biopsy. The pain was present in the period of 10 to 15 days of the procedure of insertion of the catheter, counting on the exchange of local dressing, either by the removal of the adhesive tape or transparent film or, also, the application of $5.0 \%$ alcohol solution for disinfection of the catheter ostium. Acute postoperative pain is characterized by the response of the surgical technician and, by the size of the incision, emotional state, among others ${ }^{(19)}$.

Specifically, the pain related to the Hickman ${ }^{\circledR}$ catheter implant, with greater intensity, is directly based on the complexity of the surgical procedure used. The technique requires the construction of a subcutaneous tunnel, from the puncture in the internal jugular vein to the sub-clavicle region, local of the device's exteriorization ${ }^{(3)}$, causing frequent pains of different intensities.

It is emphasized that acute pain during the hematopoietic stem cell transplantation process, as evidenced in the children of the present study, requires specific nursing interventions for their relief ${ }^{(17)}$. 
In this process, nursing has as a relevant activity the monitoring and evaluation of pain daily and in short periods of time, using scales to measure the scores, validated and adapted for each age group of the child, to provide early detection, relief and ${ }^{(14,17)}$. It is emphasized that, in addition to the use of the scales, it is necessary to carry out a focalized search for pain, through questions directed to the child or family, depending on the age and cognitive and verbal skills; verification of data contained in medical records and/ or electronic platforms. In this way, we seek the excellence of care based on scientific evidence ${ }^{(20)}$, with the main objective being the adequate management of pain.

Due to the complexity and subjectivity of pain and its intrinsic to the cognitive relation of each patient, it is imperative for the nursing professional to develop the ability to diagnose potential patient needs, converging with the effective and humanized action in pain management.

From the results obtained, local evidence was generated that pain, in the process of transplantation of hematopoietic stem cells, is a frequent sign, and affecting children, becomes even more relevant due to cognitive, reflexive and real expression abilities of intensities and sites of painful processes. Therefore, the application of scales for pain assessment requires full adhesion by the nursing and health team. In this sense, it is understood that the nurse professional takes great responsibility in motivating, qualifying and auditing the teams.

\section{Conclusion}

Pain was present throughout the hospitalization process of hematopoietic stem cell transplantation, with varied intensities. The most commonly reported sites were the mouth and the hypo pharyngeal region. Although the pain did not affect a large proportion of children, moderate and strong pains accounted for about $80.0 \%$ of complaints.
It is pointed out that the instrument used for gauging the pain, the Faces Pain Scale Revised scale, was appropriate to assess the pain children born to hematopoietic stem cell transplantation. Thus, it is suggested that the evaluation of pain is one of the signs to be inserted in the protocols of nursing interventions in this context of caring.

\section{Acknowledgments}

To the Coordenação de Aperfeiçoamento de Pessoal de Nível Superior for promoting the development of this study through the granting of scholarship.

\section{Collaborations}

Sampaio AC and Mercês NNA contributed with conception, design, analysis, data interpretation, article writing, and critical review of relevant intellectual content. Pontes $\mathrm{L}$ collaborated with the writing of the article and critical review relevant intellectual content. Tacla MTGM and Freire MHS assist in design. All authors contributed with final approval of the version to be published.

\section{References}

1. Gyurkocza B, Sandmaier BM. Conditioning regimens for hematopoietic cell transplantation: one size does not fit all. Blood [Internet.] 2014 [cited Feb 21, 2019]; 124(3):344-53. Available from: http://www.bloodjournal.org/ content $/ 124 / 3 / 344$ ?sso-checked=true

2. Merskey H, Bogduk N. Part III: pain terms, a current list with definitions and notes on usage. In: Classification of chronic pain. Seattle: IASP Press; 2012. p.209-14.

3. Gurunathan A, Patel NS, Freedman JL. Mucositis and pain in the peri-HSCT period. In: Brown VI. Hematopoietic stem cell transplantation for the pediatric hematologist/oncologist. Philadelphia: Springer; 2018. p.209-14. 
4. World Health Organization. WHO guidelines on the pharmacological treatment of persisting pain in children with medical illnesses. Geneva: World Health Organization; 2012.

5. Rodrigues HF, Garbin LM, Castanho LEC, Simões BP, Curcioli ACJV, Silveira RCCP. Cateter de Hickman no transplante de células-tronco hematopoéticas: implante cirúrgico, retirada e assistência de enfermagem. Rev Enferm UERJ. 2015; 23(3):3049. doi: dx.doi.org/10.12957/reuerj.2015.4995

6. Scher C, Meador L, Van Cleave JH, Reid MC. Moving beyond pain as the fifth vital sign and patient satisfaction scores to improve pain care in the 21st century. Pain Manag Nurs. 2017; 19(2):125-9. doi: https://doi.org/10.1016/j.pmn.2017.10.010

7. Figueiredo TWB, Mercês NNA, Nunes MBM, Wall ML. Adverse reactions on day zero of hematopoietic stem cell transplantation: integrative review. Rev Gaúcha Enferm. 2018;39:e20180095. doi: https:// doi.org/10.1590/1983-1447.2018.20180095

8. Rocha V, Kalinke LP, Felix JVC, Mantovani MF, Maftum MA, Guimarães PRB. Quality of life of hospitalized patients submitted to hematopoietic stem cells transplantation. Rev Eletr Enferm [Internet]. 2015 [cited Feb 21, 2019]; 17(4):1-9. Available from: https://www.fen.ufg.br/revista/ v17/n4/pdf/v17n4a11-en.pdf

9. Vasquenza K, Ruble K, Chen A, Billett C, Kozlowski L, Atwater S, et al. Pain management for children during bone marrow and stem cell transplantation. Pain Manag Nurs. 2015; 16(3):156-62. doi: dx.doi. org/10.1016/j.pmn.2014.05.005

10. Batalha LMC, Fernandes AN, Campos C, Gonçalvez AMPMPC. Avaliação da dor em crianças com cancro: uma revisão sistemática. Rev Enferm Ref. 2015; série IV(5):119-27. doi: http://dx.doi. org/10.12707/RIV14013

11. Azevedo DM, Nascimento VM, Azevedo IC, Cavalcanti RD, Sales LKO. Assistência de enfermagem à criança com dor: avaliação e intervenções da equipe de enfermagem. Rev Bras Pesq Saúde. 2014; 16(4):23-31. doi: https://doi.org/10.21722/rbps. v16i4.11170

12. International Association for Study of the Pain (IASP). Faces Pain Scale - revised home. Educacion. Faces Pain Scale [Internet]. 2018 [cited Feb 21, 2019]. Available from: https://wwwiasp-pain. org/Education/Content.aspx?ItemNumber=1519
13. Mendes BSO, Sales APS, Araújo OMR, Contrera L, Crispim SF, Saviczki PL, et al. Assistência a dor em um hospital de ensino. Rev Pesq Qual [Internet]. 2018 [cited Feb 21, 2019]; 10(6):11123. Disponível em: https://editora.sepq.org.br/ index.php/rpq/article/view/ 209

14. Charry CLE, Piola JS, Linhares MBM, Silva JA. Validity and realiability assessment of the Brasilian version of the faces pain scale-revised. Psychol Neurosci. 2014; 7(1):55-9. doi: dx.doi. org/10.3922/j.psns.2014.1.08

15. Le May S, Ballard A, Khadra C, Gouin S, Plint AC, Villeneuve E, et al. Comparison of the psychometric properties of 3 pain scales used in the pediatric emergency department: visual analogue scale, faces pain scale-revised, and colour analogue scale. Pain. 2018; 159(8):1508-17. doi: dx.doi. org/10.1097/j.pain.0000000000001236

16. Mazza VA, Souza C, Estevão AR, Guimarães SL, Mercês NNA. Experience of families of children and adolescents submitted to Hematopoietic Stem Cell Transplantation. Rev Eletr Enf. 2016; 18:e1193. doi: dx.doi.org/10.5216/ree.v18.40131

17. Santos JP, Maranhão DG. Cuidado de Enfermagem e manejo da dor em crianças hospitalizadas: pesquisa bibliográfica. Rev Soc Bras Enferm Ped [Internet]. 2016 [citado 2019 Fev. 27]; 16(1):4450. Disponível em: https://sobep.org.br/ revista/images/stories /pdf-revista / vol16-n1/ vol_16_n_1-artigo-de-revisao-2.pdf

18. Lopes TAMC, Monteiro MFV, Oliveira JD, Oliveira DR, Pinheiro AKB, Damasceno SS. Nursing diagnoses in hospitalized children. Rev Rene. 2017; 18(6):756-62. doi: http://dx.doi. org/10.15253/2175-6783.2017000600008

19. Kraychete DC, Sakata RK, Lannes LOC, Baneira ID, Sadatsune EJ. Postoperative persistent chronic pain: what do we know about prevention, risk factors, and treatment. Braz J Anesthesiol. 2016; 66(5):505-12. doi: https://doi.org/10.1016/j. bjan.2014.12.002

20. Santos JS, Lima LM, Melo IA. Sistematização da assistência de enfermagem na unidade de terapia intensiva: revisão bibliográfica. Ciênc Biol Saúde [Internet]. 2014 [citado 2019 Mar. 21]; 2(2):59-68. Disponível em: https://periodicos. set.edu.br/index.php/cadernobiologicas/article/ viewFile/1657/1012 